\title{
Histopathological reaction over prosthesis surface covered with silicone and polyurethane foam implanted in rats ${ }^{1}$
}

\author{
Reação histopatológica sobre a superfície de próteses cobertas por espuma de silicone e \\ poliuretano implantadas em ratos
}

\author{
Jorge Wagenführ-Júnior', Jurandir Marcondes Ribas Filho" ${ }^{\mathrm{II}}$, Marcelo Mazza do Nascimento ${ }^{\mathrm{II}}$, Fernanda Marcondes Ribas, \\ Marcus Vinícius Wanka ${ }^{\text {III }}$, Andressa de Lima Godoi ${ }^{\text {IV }}$ \\ ${ }^{I}$ Master, FEPAR, Curitiba-PR, Brazil. Main author. Conception and design of the study, critical revision. \\ IPhD, Full Professor, FEPAR, Curitiba-PR, Brazil. Supervised all phases of the study, manuscript writing, critical revision. \\ IIIFellow Master degree, Postgraduate Program in Principles of Surgery, FEPAR, Curitiba-PR, Brazil. Involved in technical procedures. \\ ${ }^{\mathrm{IV}}$ Graduate student, FEPAR, Curitiba-PR, Brazil. Involved in technical procedures.
}

\begin{abstract}
PURPOSES: To evaluate whether polyurethane foam leads more intense foreign-body reaction than silicone foam. To compare the vascularization of the capsules surrounding the foam implants. To investigate if the capsule of polyurethane foam implanted has greater amount of collagen than that of silicone foam.

METHODS: Sixty-four young male Wistar rats were allocated into two groups: polyurethane foam and silicone foam. Subcutaneous discs were implanted into the dorsum of the animals in both groups. The capsules were assessed 28 days, two months, three months and six months postoperatively. Microscopic analysis with H\&E stain was performed to evaluate the acute and chronic inflammatory process, foreign-body reaction and neovascularization. The analysis with picrosirius red was performed using the ImageProPlus software, to measure the number of vessels and collagen types I and III.

RESULTS: There were no statistical differences between the two groups regarding the acute and chronic inflammatory processes. All rats from the polyurethane group, in all times, exhibited moderate or intense foreign-body reaction, with statistic significant difference $(\mathrm{p}=0.046)$ when compared with the silicone group, in which the reaction was either mild or nonexistent at two months. Vascular proliferation was significantly different between the groups at 28 days $(\mathrm{p}=0.0002)$, with the polyurethane group displaying greater neovascularization with H\&E stain. Similar results were obtained with picrosirius red, which revealed in the polyurethane group a much greater number of vessels than in the silicone group $(\mathrm{p}=0.001)$. The collagen area was larger in the polyurethane group, significantly at 28 days $(\mathrm{p}=0.001)$ and at two months $(\mathrm{p}=0.030)$.

CONCLUSIONS: Polyurethane foam elicited more intense foreign-body reaction when compared with silicone foam. The number of vessels was higher in the capsules of the polyurethane foam implants 28 days after the operation. The capsule of the polyurethane foam implants showed a greater amount of collagen than that of the silicone foam implants.
\end{abstract}

Key words: Prostheses and Implants. Polyurethanes. Silicones. Rats.

\section{RESUMO}

OBJETIVOS: Avaliar, em relação ao uso de próteses, se a espuma de poliuretano apresenta maior reação de corpo estranho no organismo ao ser comparada com a espuma de silicone. Se há diferenças na vascularização das cápsulas formada ao redor das duas espumas implantadas. Se as cápsulas dos implantes de espuma de poliuretano apresentam quantidade maior de fibras colágenas ao serem comparadas com as da espuma de silicone.

MÉTODOS: Utilizou-se 64 ratos albinos da linhagem Wistar, distribuídos em dois grupos de 34, grupo espuma de poliuretano e grupo espuma de silicone e receberam implantes discóides subcutâneos em seu dorso. Foram analisadas as cápsulas peri-implante com 28 dias, dois, três e seis meses após a introdução. A análise microscópica com H\&E considerou as variáveis: inflamação aguda, inflamação 
crônica, reação de corpo estranho e neoformação vascular. A análise da coloração com picrosirius-red usando ImageProPlus considerou o número de vasos e colágeno tipo I e tipo III.

RESULTADOS: Em relação à inflamação aguda e crônica, não foram encontradas diferenças estatísticas nos dois grupos. Todos os animais do grupo poliuretano, em todos os momentos, apresentaram reação de corpo estranho moderada ou intensa e foi encontrada diferença estatística significativa $(\mathrm{p}=0,046)$ ao serem comparados com o grupo silicone, cuja reação era ausente ou discreta aos dois meses. A neoformação vascular apresentou diferenças significativas nos dois grupos, aos 28 dias ( $p=0,0002$ ); o grupo poliuretano com H\&E apresentava quantidade maior de vasos neoformados e o mesmo ocorrendo com o picrosirius, cujo número de vasos era maior que no grupo silicone $(\mathrm{p}=0,001)$. A área de colágeno em todos os momentos foi maior no grupo poliuretano, sendo significativa com 28 dias $(p=0,001)$ e com dois meses $(p=0,030)$.

CONCLUSÕES: A espuma de poliuretano apresentou maior reação de corpo estranho no organismo do que a espuma de silicone. A quantidade de vasos foi maior na cápsula da espuma de poliuretano com 28 dias após o implante. Aos 28 dias as cápsulas dos implantes de espuma de poliuretano apresentaram quantidade significativamente maior de colágeno do que as de espuma de silicone.

Descritores: Próteses e Implantes. Poliuretanos. Silicones. Ratos.

\section{Introduction}

The demand for breast substitute, both in its absence or in hypoplasia, has long story of failures till the advent of silicone prosthesis $^{1-7}$.

The first implant of silicone gel was developed by Cronin and Gerow ${ }^{8}$. It was submitted to a series of changes mainly on aspect of surface, firstly characterized by smooth texture. Although the innovations had raised the degree of patient satisfaction, in comparison with the previous methods, the new prosthesis lost in symmetry, infection rates and complications, mainly capsular contracture. This contracture is defined as strange body reaction forming tissue contraction around the implant. Histologically, consists of several layers - fibroblasts, fibrocytes, myofibroblasts and histiocytes - involved by acellular tissue rich in collagen. This layer is circular and contracts over the implant and products signs and symptoms that may vary from discomfort and breast stiffening to intractable pain, loss of mobility and important deformity.

Searching for better results, modifications on prosthesis structure were made, especially on the quality of material focusing reactivity to gel, thickness and greater resistance. Attempts to diminish capsular contractures resulted on the development of prosthesis with rough surface. But the intensity of inflammatory reaction around did not change. Although the final force vector of retraction on prosthesis was reduced, the experience was insufficient ${ }^{9}$ to give a final opinion.

In the 70's, were developed implants covered with polyurethane foam ${ }^{10}$. For many years they were employed with success $^{11,12}$, but some problems ${ }^{13,14}$ guided to the definition of what would be the ideal implant ${ }^{15}: 1$ ) no physical modification on tissues; 2) be chemically inert; 3) no carcinogenic activity;
4) no tissue reaction; 5) be non allergenic; 6) no body strange reaction; 7) resistant to mechanical forces; and 8) possibility to be manufactured in desired format.

Lodovici et $a l .{ }^{16}$ referred that silicone satisfies the requirements; perhaps this is the reason why it is more used. For an ideal implant, the security and effectiveness should include good histopathological interface - implant/tissue - and the possibility to occur less chronic and granulomatous inflammation. Experimental studies aiming to get fewer reaction and good tissue repair must be done ${ }^{17}$. The study of Wagenführ ${ }^{18}$, treis to correlate the microporous structure of polyurethane coating with the biocompatibility of silicone.

The objectives of this research using prosthesis were to verify: a) if the foam of polyurethane leads to more strange body reaction compared to silicone foam; b) if there are differences in vascularization around of two foams; c) if polyurethane implants exhibit more collagen reaction compared to the ones of silicone.

\section{Methods}

This study was performed at the Post-graduate Program in Principles of Surgery, Evangelic Faculty of Parana / University Evangelic Hospital of Curitiba / Medical Research Institute, Curitiba-PR, Brazil after approval of the Ethics Committee of Beneficent Evangelic Society number 4949/05.

Sixty four rats Wistar (Rattus norvegicus albinos), young male adults were used with weight ranging between 210-250g. During all the experiment they remained in appropriate place with controlled temperature and luminosity with free access to water and diet.

They were distributed into two groups of 32 , and 
subdivided in four subgroups of eight animals to be analyzed on 28 days and two, three and six months after the experiment.

The animals had inclusion of discoid implants of $20 \mathrm{~mm}$ in diameter, presenting all the layers of a clinical mammary implant. Each group received one type of implant. On group polyurethane $(n=32)$ was implanted polyurethane foam $\left(\right.$ Silimed $\left.^{\circledR}\right)$. On group silicone $(n=32)$ was implanted silicone foam $\left(\right.$ Lifesi $\left.^{\circledR}\right)$ (Figure 1).

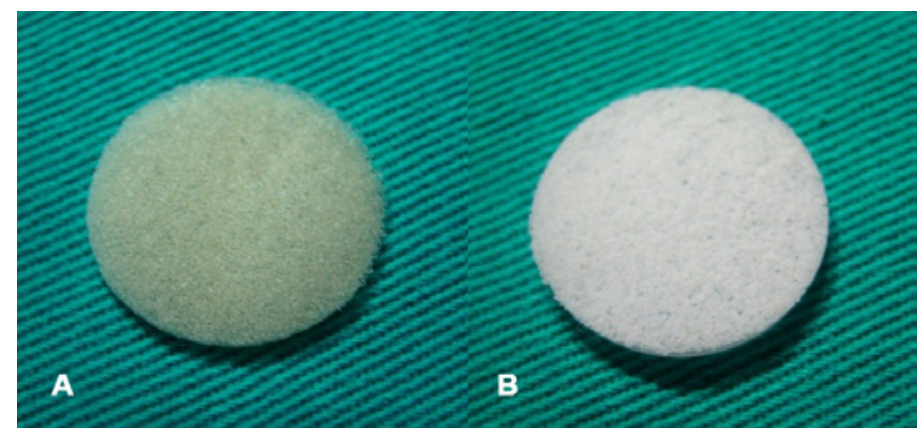

FIGURE 1 - Implants. A. Polyurethane. B. Silicone.

The rats were anaesthetized by intraperitoneal injection of hydrochloride ketamine $\left(\operatorname{Ketalar}^{\circledR}\right) 50 \mathrm{mg} / \mathrm{ml}$ and chlorpromazine $\left(\right.$ Thorazine $^{\circledR}$ ) $5 \mathrm{mg} / \mathrm{ml}$ in a proportion of $10 / 1,5 \mathrm{ml}$ respectively. The induction was done with $0.9 \mathrm{ml}$ of $\operatorname{Ketalar}^{\circledR}$ diluted in $0.135 \mathrm{ml}$ of Thorazine ${ }^{\circledR}$. They were positioned in ventral decubitus with trichotomy in region dorsal. Normal antisepsis was done. At this moment, they were randomized between the two foam types. In Figure 2 can be observed the prosthesis with surfaces of polyurethane and with silicone foams.

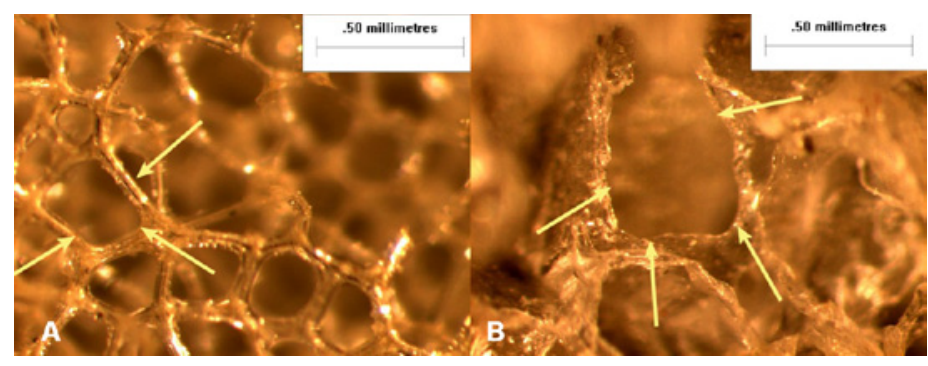

FIGURE 2 - Photomicrographs of the foams. A. Implant of polyurethane. B. Implant of silicone (57x).

Note: Arrows points in A polyurethane mesh and in $\mathbf{B}$ the walls of silicone.

For delimitation of incision and location of implants, an intercostal horizontal line intercepted with a sagittal one was done. In the crossing point of the lines a horizontal incision on back with $1 \mathrm{~cm}$ was carried out. With scissors, a space to fit subcutaneously the implants was created in cranial sense with diameter approximately the same as the implants (Figure 3). Skin closure was done with mononylon 4-0 and the wound was always freely exposed.

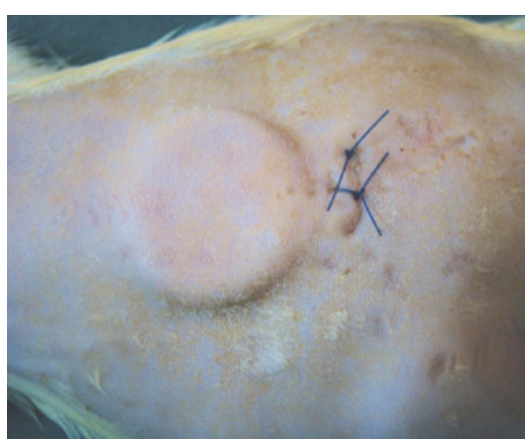

FIGURE 3 - Implant in surgical position.

After each observation time group, the animals were reoperated with anesthesia similar to of first operation. The surgical specimens had margins containing the edges of implants, skin and muscular layer (Figure 4).

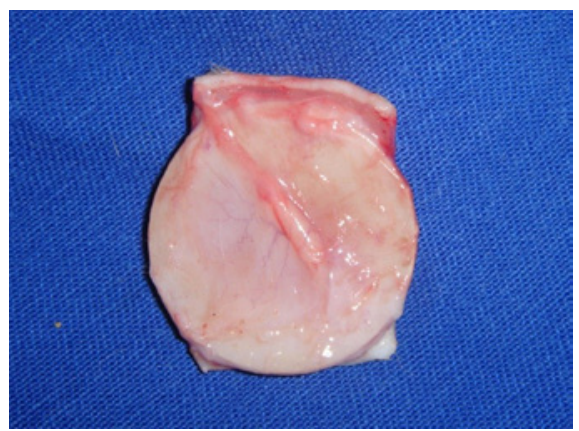

FIGURE 4 - Surgical specimen after withdrawal from surgical site.

The rats were dead by lethal inhalation of sulfuric ether in the subgroups of 28 days and two, three and six months postoperatively. The specimen was fixed in formol $10 \%$ and histological sections included transverse and centralized incisions which were analyzed with the tissues and implant. Stainings with hematoxylin-eosin (H\&E) and picrosirius (Sirius red) were used.

H\&E served to evaluate cellular elements and capillaries, looking at the presence of: a) acute inflammation (quantity of neutrophils and polymorphonuclear cells); chronic inflammation through infiltrative lymphoplasmocitaries cells; c) strange body reaction by giant cells; and d) vascular neoformation. To analyze the intensity of reaction, it was classified into four degrees: absent, discrete, moderate and intense.

Picrosirius red was used to measure field vessel proliferation, and area with collagen in square micra.

For the comparisons between the groups of polyurethane and silicone, and the days of evaluation in relationship to microscopic analysis, was used the Fisher test grouping degrees: 1) absent and discrete, and 2) moderate and intense. For the analysis of variables of collagen was used the test nonparametric of MannWhitney. Values of $\mathrm{p}<0.05$ indicated statistic significance. 


\section{Results}

In all the animals and in all moments of evaluation occurred absence or discrete presence of acute inflammation (Table 1).

TABLE 1 - Acute inflammation in several moments of the implants.

\begin{tabular}{ccccc} 
Time & Classification & $\begin{array}{c}\text { Group } \\
\text { polyurethane }\end{array}$ & $\begin{array}{c}\text { Group } \\
\text { silicone }\end{array}$ & $\begin{array}{c}\text { Polyurethanexsilicone } \\
\text { p value }\end{array}$ \\
28 days & Absent/discrete & 8 & 7 & 1 \\
& Moderate/intense & 0 & 0 & 1 \\
2 months & Absent/discrete & 7 & 5 & 1 \\
& Moderate/intense & 0 & 0 & \\
3 months & Absent/discrete & 7 & 5 & 1 \\
\cline { 2 - 4 } 6 months & Moderate/intense & 0 & 0 & \\
& Absent/discrete & 6 & 8 & 1 \\
\cline { 2 - 4 } & Moderate/intense & 0 & 0 &
\end{tabular}

Regarding the chronic inflammation in polyurethane group with 28 days, all animals presented it as absent or discrete; but in two months, about half of animals had it as moderate or intense. On silicone group, was observed absence or discrete presence in all animals in the four moments of evaluation. No significant differences were found between groups (Table 2).

TABLE 2 - Chronic inflammation in several moments comparing the foam groups, polyurethane and silicone.

\begin{tabular}{|c|c|c|c|c|}
\hline Time & Classification & $\begin{array}{c}\text { Group } \\
\text { polyurethane }\end{array}$ & $\begin{array}{l}\text { Group } \\
\text { silicone }\end{array}$ & $\begin{array}{c}\text { PolyurethanexSilicone } \\
\text { p value }\end{array}$ \\
\hline \multirow{2}{*}{28 days } & Absent/discrete & 8 & 6 & \multirow{2}{*}{0.467} \\
\hline & Moderate/intense & 0 & 1 & \\
\hline \multirow{2}{*}{2 months } & Absent/discrete & 3 & 5 & \multirow{2}{*}{0.081} \\
\hline & Moderate/intense & 4 & 0 & \\
\hline \multirow{2}{*}{3 months } & Absent/discrete & 4 & 5 & \multirow{2}{*}{0.204} \\
\hline & Moderate/intense & 3 & 0 & \\
\hline \multirow{2}{*}{6 months } & Absent/discrete & 4 & 8 & \multirow{2}{*}{0.165} \\
\hline & Moderate/intense & 2 & 0 & \\
\hline
\end{tabular}

All the animals of polyurethane group, in all the times, presented moderate or intense foreign body reaction (Figure 5A), while in the silicone group it was absence or discrete (Figure 5B).

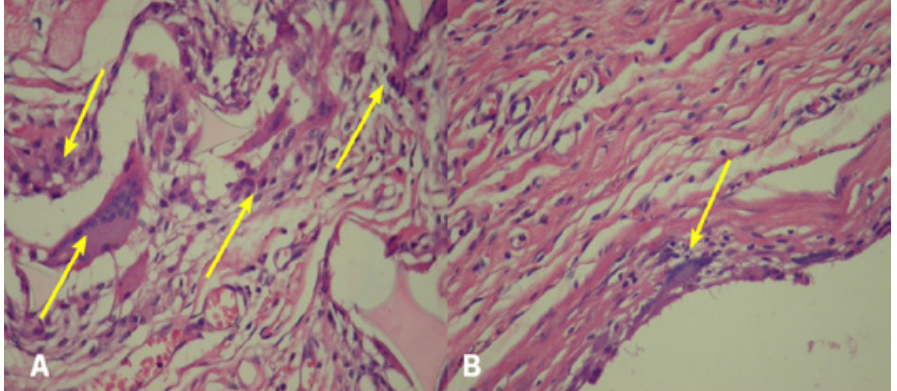

FIGURE 5 - Photomicrographs with strange body reaction. A. Intense in polyurethane foam. B. Discrete in silicone (200x).

Note: In $\mathbf{A}$, arrows indicate great amount of giant cells and in $\mathbf{B}$ only one cell giant.

It was found significant difference $(\mathrm{p}=0.046)$ in foreign body reaction between the groups in two months (Table 3 ).

TABLE 3 - Strange body reaction in several moments of implants

\begin{tabular}{|c|c|c|c|c|}
\hline Time & Classification & $\begin{array}{c}\text { Group } \\
\text { polyurethane }\end{array}$ & $\begin{array}{l}\text { Group } \\
\text { silicone }\end{array}$ & $\begin{array}{c}\text { PolyurethanexSilicone } \\
\text { p value }\end{array}$ \\
\hline \multirow{2}{*}{28 days } & Absent/discrete & 0 & 2 & \multirow{2}{*}{0.200} \\
\hline & Moderate/intense & 8 & 5 & \\
\hline \multirow{2}{*}{2 months } & Absent/discrete & 0 & 3 & \multirow{2}{*}{0.046} \\
\hline & Moderate/intense & 7 & 2 & \\
\hline \multirow{2}{*}{3 months } & Absent/discrete & 0 & 1 & \multirow{2}{*}{0.417} \\
\hline & Moderate/intense & 7 & 4 & \\
\hline \multirow{2}{*}{6 months } & Absent/discrete & 0 & 2 & \multirow{2}{*}{0.472} \\
\hline & Moderate/intense & 6 & 6 & \\
\hline
\end{tabular}

The vascular neoformation was statistically significant into the two groups with 28 days ( $p=0.0002$ ). While all the animals of group polyurethane had presence of moderate or intense reaction (Figure 6A), on silicone group it was absent or discrete in all animals (Figure 6B).

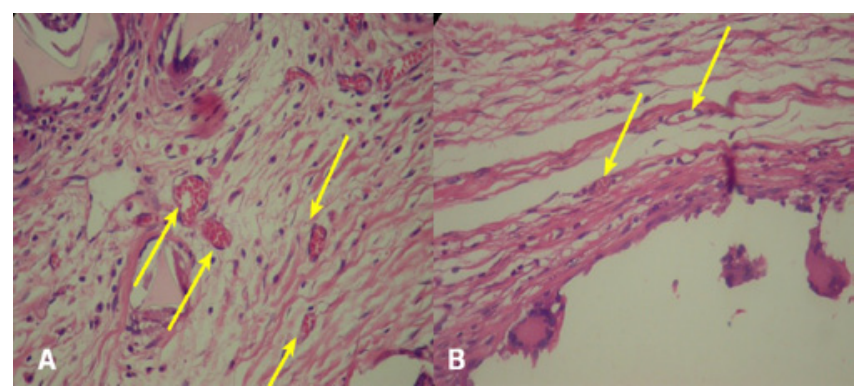

FIGURE 6 - Photomicrographs. A. Polyurethane foam with evidence of marked vascular neoformation. B. Silicone foam with discrete neoformation (200x).

Note: In $\mathbf{A}$, arrows indicate vessels and blood into the vessels and in $\mathbf{B}$, small amount of vessels. 
In two months the two groups, in the majority of the animals, had absence or discrete presence of vascular neoformation (Table 4).

TABLE 4 - Vascular neoformation in several moments comparing the groups, polyurethane and silicone foam.

\begin{tabular}{|c|c|c|c|c|}
\hline Time & Classification & $\begin{array}{c}\text { Group } \\
\text { polyurethane }\end{array}$ & $\begin{array}{l}\text { Group } \\
\text { silicone }\end{array}$ & $\begin{array}{c}\text { PolyurethanexSilicone } \\
\text { p value }\end{array}$ \\
\hline \multirow{2}{*}{28 days } & Absent/discrete & 0 & 7 & \multirow{2}{*}{0.0002} \\
\hline & Moderate/intense & 8 & 0 & \\
\hline \multirow{2}{*}{2 months } & Absent/discrete & 7 & 4 & \multirow{2}{*}{0.417} \\
\hline & Moderate/intense & 0 & 1 & \\
\hline \multirow{2}{*}{3 months } & Absent/discrete & 7 & 5 & \multirow{2}{*}{1} \\
\hline & Moderate/intense & 0 & 0 & \\
\hline \multirow{2}{*}{6 months } & Absent/discrete & 6 & 8 & \\
\hline & Moderate/intense & 0 & 0 & \\
\hline
\end{tabular}

In relationship to collagen with 28 days, there was significant difference between the groups $(p=0.001)$, being more pronounced on group polyurethane. Vessels occurred in greater amount on polyurethane group (Figure 7A), when compared with the group of silicone $(\mathrm{p}=0.001)$ (Figure $7 \mathrm{~B})$.

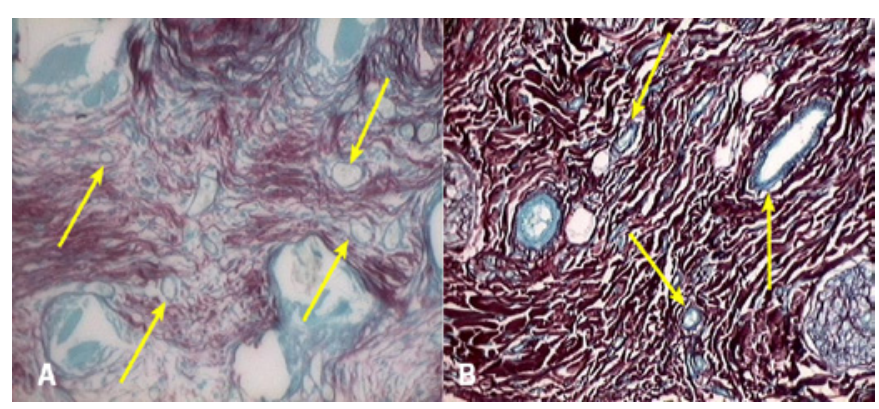

FIGURE 7 - Photomicrographs on 28 days subgroups. A. Polyurethane foam. B. Silicone foam (200x).

Note: Arrows in $\mathbf{A}$ indicate vessels and ten vessels in collagen area of 6333.01 square micra and in $\mathbf{B}$, arrows indicate the vessels and three vessels in the area of collagen of 90.20 square micra.

The number of vessels is described in Table 5 .

(table 5, 6, 7 and 8 - next page)
In this study the polyurethane foam presented moderate proliferation with little inflammatory reaction, but with great number of multinucleated giant cells encompassing partly the material of prosthesis, denoting an inflammatory typical process of strange body. These facts were also found by others ${ }^{19-21}$.

As Lyras $^{19}$ reported, in this research the implants of silicone coated by polyurethane provoked, at the beginning, acute inflammatory reaction that continued with intense phagocytosis of coating material.

In silicone implants proliferation of conjunctive tissue with moderate inflammatory reaction was mixed with giant cells multinucleated.

With similar structure to the one of polyurethane, the silicone foam has a close position looking for the ideal foam, and it seems to be a good option for coating implants of silicone. This study proved biocompatibility, with less inflammatory or strange body reaction and without the biodegradable components that the polyurethane presents.

Acute inflammatory reaction presents edema, leukocytes and especially neutrophils ${ }^{22}$. Kafejian et al. ${ }^{23}$ found greater amount of neutrophils on third day around the implants, but not on 30 days. Kamelger et al. ${ }^{24}$ observed significant reduction of neutrophils comparing seven and 30 days. They tested the polymers with historic data of false healing procedures and with two copolymers named acid polyethylene-acrylic and micropores acid acrylicpolypropylene. On present study there was absence of neutrophils with 28 days $^{23,24}$, and no differences between polyurethane and silicone foam for acute inflammation.

On the mechanisms that leads to fibroblastic and vascular proliferation, are factors that derive from macrophages and are implicated in both fibroblastic proliferation ${ }^{25}$ and growth of new vessels. The greater number of vessels observed on group polyurethane, on present study, can be explained by these factors.

To compare the inflammatory reaction caused by the implant of textured silicone with the same reaction caused by the implant of textured silicone covered by E-PTFE Haddad Son et $a l .{ }^{26}$ observed that both induced chronic inflammatory reaction and weak inflammatory reaction type strange body similar to the present study.

Balderrama et al. ${ }^{27}$ compared silicone foams and textured implants finding no differences in inflammatory reactions. In this study was observed differences in regard only to chronic inflammatory process.

The formation of granulomas can be determined by the presence of indigestible agents, as particles of mineral oil, polysaccharides and polymers. Experimental studies however, 
TABLE 5 - Moment of 28 days with number of vessels and area of collagen.

\begin{tabular}{|c|c|c|c|c|c|c|c|c|}
\hline Variable & Group & $\mathbf{n}$ & Average & Median & Minimum & Maximum & $\begin{array}{c}\text { Standard - } \\
\text { deviation }\end{array}$ & p value* \\
\hline \multirow{2}{*}{$\begin{array}{c}\text { Number of } \\
\text { vessels }\end{array}$} & Polyurethane & 8 & 8.38 & 8.50 & 5.00 & 11.00 & 2.00 & \\
\hline & Silicone & 7 & 3.14 & 3.00 & 1.00 & 5.00 & 1.68 & 0.001 \\
\hline \multirow{2}{*}{$\begin{array}{l}\text { Area of } \\
\text { collagen }\end{array}$} & Polyurethane & 8 & 4909.17 & 5562.85 & 1211.86 & 8683.94 & 2861.75 & \\
\hline & Silicone & 7 & 368.73 & 153.66 & 87.72 & 1644.84 & 566.66 & 0.001 \\
\hline
\end{tabular}

(*)Test nonparametric of Mann-Whitney $(\mathrm{p}<0.05)$.

After two months, collagen area was greater on group polyurethane than in silicone. In relationship do number of vessels, was not found significant difference between the groups. There was statistic difference between groups when was compared the collagen area $(\mathrm{p}=0.030)($ Table 6$)$.

TABLE 6 - Subgroups of two months comparing number of vessels and collagen area.

\begin{tabular}{|c|c|c|c|c|c|c|c|c|}
\hline Variable & Group & $\mathbf{n}$ & Average & Median & Minimum & Maximum & $\begin{array}{c}\text { Standard - } \\
\text { deviation }\end{array}$ & p value* \\
\hline \multirow{2}{*}{$\begin{array}{c}\text { Number of } \\
\text { vessels }\end{array}$} & Polyurethane & 7 & 5.00 & 5.00 & 3.00 & 7.00 & 1.29 & \\
\hline & Silicone & 5 & 6.20 & 5.00 & 3.00 & 11.00 & 3.03 & 0.639 \\
\hline \multirow{2}{*}{$\begin{array}{l}\text { Area of } \\
\text { collagen }\end{array}$} & Polyurethane & 7 & 658.90 & 567.36 & 103.89 & 1498.65 & 475.10 & \\
\hline & Silicone & 5 & 160.88 & 156.77 & 92.07 & 238.27 & 55.18 & 0.030 \\
\hline
\end{tabular}

(*)Test nonparametric of Mann-Whitney $(\mathrm{p}<0.05)$.

In three months of observation, no significant statistic difference between the groups was found in relationship to number of vessels and collagen area (Table 7).

TABLE 7 - Moment of three months comparing number of vessels and collagen area.

\begin{tabular}{|c|c|c|c|c|c|c|c|c|}
\hline Variable & Group & $\mathbf{n}$ & Average & Median & Minimum & Maximum & $\begin{array}{l}\text { Standard - } \\
\text { deviation }\end{array}$ & p value* \\
\hline \multirow{2}{*}{$\begin{array}{c}\text { Number of } \\
\text { vessels }\end{array}$} & Polyurethane & 7 & 3.86 & 4.00 & 3.00 & 5.00 & 0.69 & \\
\hline & Silicone & 5 & 4.60 & 4.00 & 2.00 & 7.00 & 1.95 & 0.530 \\
\hline \multirow{2}{*}{$\begin{array}{l}\text { Area of } \\
\text { collagen }\end{array}$} & Polyurethane & 7 & 1420.00 & 1032.07 & 180.41 & 4749.14 & 1648.44 & \\
\hline & Silicone & 5 & 818.07 & 661.30 & 398.77 & 1792.28 & 573.95 & 1 \\
\hline
\end{tabular}

(*)Test nonparametric of Mann-Whitney $(\mathrm{p}<0.05)$.

Comparing the groups with six months, the area of collagen and the number of vessels had no statistic significant differences. After six months of the operation also no differences were found when were compared the two groups (Table 8).

TABLE 8 - Subgroup of six months comparing number of vessels and area of collagen.

\begin{tabular}{|c|c|c|c|c|c|c|c|c|}
\hline Variable & Group & $\mathbf{n}$ & Average & Median & Minimum & Maximum & $\begin{array}{c}\text { Standard - } \\
\text { deviation }\end{array}$ & p value* \\
\hline \multirow{2}{*}{$\begin{array}{c}\text { Number of } \\
\text { vessels }\end{array}$} & Polyurethane & 6 & 4.17 & 4.50 & 1.00 & 6.00 & 1.72 & \\
\hline & Silicone & 8 & 7.25 & 7.50 & 3.00 & 12.00 & 3.20 & 0.108 \\
\hline \multirow{2}{*}{$\begin{array}{l}\text { Area of } \\
\text { collagen }\end{array}$} & Polyurethane & 6 & 677.89 & 425.83 & 146.19 & 1865.69 & 623.97 & \\
\hline & Silicone & 8 & 354.37 & 309.19 & 100.16 & 708.58 & 223.23 & 0.282 \\
\hline
\end{tabular}

$\left({ }^{*}\right)$ Test nonparametric of Mann-Whitney $(\mathrm{p}<0.05)$. 
show that granulomatous inflammation can be potentiated by immunity ${ }^{28,29}$.

The strange body reaction in this study was moderate or intense for all animals of polyurethane group and in all the times. On silicone group there were animals with absence or discrete presence of reaction with significant difference between the groups in two months. This is a very important fact, because it suggests that foam of silicone has more biocompatibility in relationship to polyurethane.

The simpler and easier method to quantify collagen is the Picrosirius Red $\mathrm{F}_{3} \mathrm{BA}^{30}$. It comes from picric acid and was used by Bucky et al. ${ }^{31}$ to compare collagen around smooth, textured and polyurethane implants; they concluded that there was less collagen type III around of prosthesis with the textured. In the evaluation of collagen disposition with picrosirius, Minami et $a l .^{32}$ found predominance of type III in the beginning and collagen type I, after 270 days. Also comparing plain and textured implants in pigs no difference on type of collagen between the groups was found. The present study corroborates to the ones above mentioned, because it was found here less collagen type III around implant of silicone foam compared with the polyurethane.

\section{Conclusions}

Polyurethane foam elicited more intense foreign-body reaction when compared with silicone foam. The number of vessels was higher in the capsules of the polyurethane foam implants 28 days after the operation. The capsule of the polyurethane foam implants showed a greater amount of collagen than that of the silicone foam implants.

\section{References}

1. Berson M. Derma-fat transplant used in building up the breasts. Surgery. 1945;15:451.

2. Campos ACL, Borges-Branco A, Groth AK. Cicatrização de feridas. ABCD Arq Bras Cir Dig. 2007;20(1):51-8.

3. Bames HO. Augmentation mammoplasty by lipotransplant. Plast Reconstr Surg (1946). 1953;11(5):404-12.

4. Bames HO. Breast malformations and a new approach to the problem of small breast. Plast Reconstr Surg (1946). 1950;5(6):499-506.

5. Luque DF. Aumento das mamas com enxerto dermatogordurosos. Ann Acad Méd Quir Esp. 1962;79:225-30.

6. Edwards BF. Teflon silicone breast implants. Plast Reconstr Surg. 1963;32:519-26

7. Chem RC. Plástica mamária estética de aumento com a utilização de próteses. Rev Soc Bras Cir Plast. 1991;6(1):28.

8. Glicenstein J. History of augmentation mammaplasty. Ann Chir Plast Esthet. 2005;50(5):337-49.

9. Michelow BJ, Hugo B. Augmentation mammoplasty. S Afr J Surg. 1988;26(3):113-4.
10. Ashley FL. A new type of breast prosthesis. Preliminary report. Plast Reconstr Surg. 1970;45(5):421-4.

11. Shons AR, Schubert W. Silicone breast implants and immune disease. Ann Plast Surg. 1992;28(5):491-9.

12. Handel N, Wellisch D, Silverstein MJ, Jensen JA, Waisman E. Knowledge, concern, and satisfaction among augmentation mammaplasty patients. Ann Plast Surg. 1993;30(1):13-20.

13. Eppley BL, Sidner RA, Sadove AM. Adequate preclinical testing of bioplastique injectable material? Plast Reconstr Surg. 1992;89(1):157-8.

14. Pollock H. Breast capsular contracture: a retrospective study of textured versus smooth silicone implants. Plast Reconstr Surg. 1993;91(3):404-7.

15. Scales J. Tissue reaction to synthetic materials. Proc R Soc Med. 1953;46(8):647-52.

16. Lodovici O, Camargo JLF, Spina V, Tsuzuki S, Freitas AG, Behmer OA. Silicone para inclusão cirúrgica: estudo comparativo de reações tissulares a matéria prima de duas procedências. Rev Assoc Med Bras. 1972;18:29-34.

17. Silver FH, Mass CS. Biology of synthetic facial implant materials. Facial Plast Surg Clin North Am. 1994;2:241-53.

18. Wagenfuhr Jr J. Análise histopatológica comparativa das cápsulas dos implantes de espumas de silicone e poliuretano em ratos. Rev Soc Bras Cir Plast. 2007;22(1):19-23.

19. Lyras I. Reação tissular a implantes de silicone com superfície lisa e rugosa - Estudo experimental, comparativo e analítico, em ratos. Rev Soc Bras Cir Plast Estet Reconstr. 1993;8:142-7.

20. Vázquez G. A ten-year experience using polyurethane-covered breast implants. Aesthetic Plast Surg. 1999;23(3):189-96.

21. Daniels AU. Silicone breast implant materials. Swiss Med Wkly. 2012;142:w13614

22. Felländer-Tsai L, Reinholt FP, Turan I. Complications with infection and foreign body reaction after silicon implant arthroplasty in the second metatarsophalangeal joint in an adolescent: a case report. J Foot Ankle Surg. 1997;36(6):452-6.

23. Kafejian AP, Haddad Filho D, Guidugli Neto J, Goldenberg S. Comparative study of the tecidual reactions of silicone and expanded politetrafluoroetilene implanted at back of the rats. Acta Cirg. Bras. 1997;12(3):182-8.

24. Kamelger FS, Marksteiner R, Margreiter E, Klima G, Wechselberger G, Hering S, Piza H. A comparative study of three different biomaterials in the engineering of skeletal muscle using a rat animal model. Biomaterials. 2004;25(9):1649-55.

25. Leibovich SJ, Ross R. The role of the macrophage in wound repair. A study with hydrocortisone and antimacrophage serum. Am J Pathol. 1975;78(1):71-100.

26. Haddad Filho D, Zveibel DK, Alonso N, Gemperli R. Comparison between textured silicone implants and those bonded with expanded polytetrafluoroethylene in rats. Acta Cir Bras. 2007;22(3):187-94.

27. Balderrama CMSR, Ribas-Filho JM, Malafaia O, Czeczko NG, Dietz UA, Sakamoto DG, Bittencourt LP. Healing reaction to mammary prostheses covered by textured silicone and silicone foam in rats. Acta Cir Bras. 2009;24(5):367-76.

28. Unanue ER, Benacerraf B. Immunological events in experimentally induced granulomas. Am J Pathol. 1973;71:349.

29. Meza Britez ME, Caballero Llano C, Chaux A. Periprosthetic breast capsules and immunophenotypes of inflammatory cells. Eur J Plast Surg. 2012;35(9):647-51.

30. Constantine VS, Mowry RW. Selective staining of human dermal collagen. II. The use of picrosirius red F3BA with polarization microscopy. J Invest Dermatol. 1968;50(5):419-23.

31. Bucky LP, Ehrlich HP, Sohoni S, May JW Jr. The capsule quality of saline-filled smooth silicone, textured silicone, and polyurethane 
implants in rabbits: a long-term study. Plast Reconstr Surg. 1994;93(6):1123-31.

32. Minami E, Koh IH, Ferreira JC, Waitzberg AF, Chifferi V, Rosewick TF, Pereira MD, Saldiva PH, de Figueiredo LF. The composition and behavior of capsules around smooth and textured breast implants in pigs. Plast Reconstr Surg. 2006;118(4):874-84.

\section{Correspondence:}

Jorge Wagenführ Junior

Alameda Augusto Stellfeld, 1980

80730-150 Curitiba - PR Brasil

Tel.: (55 41)3240-5488

ipem@evangelico.org.br

Received: July 18, 2012

Review: September 19, 2012

Accepted: October 22, 2012

Conflict of interest: none

Financial source: none

${ }^{1}$ Research performed at Postgraduate Program in Principles of Surgery, Evangelic Faculty of Parana (FEPAR), Evangelic University Hospital, Curitiba-PR, Brazil. 